\title{
Patterns of Recovery from Low Numbers in Namib Desert Rodents
}

\author{
Donald P. CHRISTIAN ${ }^{1}$
}

\begin{abstract}
Christian D. P., 1980: Patterns of recovery from low numbers in Namib Desert rodents. Acta theriol., 25, 37: 431-450 [With 5 Tables \& 1 Fig.].

Patterns of growth were examined in eight populations of three Namib Desert rodent species during 1974 and 1975. Initial density of all populations was extremely low following an apparent droughtinduced reproductive failure the previous year. Subsequent to high rainfall and good plant production in early 1974, all populations recovered from low numbers. Gerbillurus paeba, Aethomys namaquensis, and one population of Desmodillus auricularis increased at rates approximately equivalent to a doubling in population size each month, reached peak numbers in September or October 1974, and subsequently declined in numbers. Other populations of $D$. auricularis grew more slowly but over a longer portion of the year, attaining peak numbers in March-April 1975. Breeding activity in most populations declined during portions of the hot dry season. In most populations, rates of increase were positively correlated with recruitment rates and inversely correlated with survival rates. The lowest density populations were characterized by a syndrome of low recruitment rates, suggesting poor reproductive success or high juvenile mortality, and a positive relationship between growth rates and survival rates. Survival rates in most populations were inversely related to breeding activity; this relationship was particularly strong for lactating females in all populations of G. paeba and one population of D. auricularis. sity].

[The Museum and Department of Zoology, Michigan State Univer-
\end{abstract}

\section{INTRODUCTION}

Both the magnitude and the timing of annual rainfall in most desert environments are quite unpredictable. Reproductive performance in many desert-dwelling rodents is strongly dependent on this rainfall and the resulting primary production (B e a tley, 1969, 1976; French et al., 1974; M c Culloch \& Inglis, 1961; R ey nolds, 1958). As a result, desert rodents often exhibit considerable year-to-year variability in reproductive activity. For example, French et al. (1974) observed annual pregnancy rates that ranged from 0 , in years of low plant production, to about 90 per cent, in years of high plant production, in

1 Present address: Department of Biology, University of Minnesota - Duluth, Duluth, MN 55803, U.S.A.

[431] 
a population of Perognathus formosus during 6 successive years. Additionally, litter sizes were larger and incidence of breeding by youngof-the year higher in years of good plant production (F r e $\mathrm{ch}$ et al., 1974). Conley et al. (1977) and $\mathrm{Nichols}$ et al. (1976) provide discussion $_{5}$ of the adaptive importance of these reproductive patterns.

One corsequence of this annual variation in reproduction is frequent marked fluctuations in density (B e a t le y, 1969; F re n ch et al., 1974; $\mathrm{R}$ e y nolds, 1958). With high reproductive rates in favorable years, rodent numbers may increase substantially. With little or no reproduction in a single year of low rainfall and poor plant growth, or in several consecutive years, rodent populations may be reduced to extremely low densities. In addition to surviving these non-reproductive periods, one of the major demographic problems faced by these animals is recovering from the resulting low numbers upon the return of favorable conditions. While this problem has been considered for Perognathus formosus (Conley et al., 1977; French et al., 1974), there are relatively few data on growth of other desert rodent populations whose numbers have been reduced following a reproductive pause of one or more years, and such information is almost completely lacking for rodents from deserts outside of North America. Because the ability to recover from these population lows is a critical demographic attribute of desert rodents, and probably a general one, more thorough knowledge of patterns of population growth under these circumstances is essential to understanding population processes in these organisms. The present study examines population growth and associated demographic events in three desert rodent species during a year following a severe reduction in density.

\section{STUDY AREA}

This study was conducted during 1974 and 1975 at Gorrasis $\left(25^{\circ} 18^{\prime} \mathrm{S}, 15^{\circ} 55^{\prime} \mathrm{E}\right)$, a non-working sheep ranch on the eastern edge of the Namib Desert in southern Africa. Data on temperature and rainfall during the study have been reported elsewhere (Christian, 1977, 1979a) and are only briefly summarized here. The climate of this region is highly arid (mean annual rainfall less than $100 \mathrm{~mm}$ ) and strongly seasonal. The rainy season coincides with the hot summer months of December through March or April, during which mean daily maximum temperatures may be as high as 36 to $38^{\circ} \mathrm{C}$. The winter months of May through August aie characterized by cooler days, nighttime temperatures that often fall below freezing, and occasional condensation in the form of fog or dew. Rainfall in 1974 (at least $165 \mathrm{~mm}$ ) was the heaviest in the area in many years; total rainfall in 1975 varied between 60 and $120 \mathrm{~mm}$ among local areas. Rainfall in 1973 was extremely low, with as little as $12 \mathrm{~mm}$ falling on some neighboring areas.

Excluding steep rocky hillsides and river beds, four major habitats for small mammals exhst in this area. These are herein termed sand dune, gravel plain, 
rock plain, and bush plain. Demographic data for small mammals in the bush plain habitat have been reported elsewhere ( $\mathrm{Chr}$ istian, 1977, 1979a) and are presented here in modified form for comparisons with the other three habitats.

One live-trap grid (described below) was established in each of the four habitats. The dune grid was located on the sloping (approximately $10^{\circ}$ ) north-tonortheast face of a southward projecting dune. The nearest edge of the grid was about $130 \mathrm{~m}$ below the dune crest, and sand at the grid site was well solidified. The gravel plain habitat, characteristic of much of this region (C o e t $\mathrm{z}$ e e, 1969), is typified by fine gravel (up to about $2 \mathrm{~mm}$ in dianeter) overlying sandy soil. The live-trap grid in this habitat was located on a very gentle (less. than $5^{\circ}$ ) northeast-facing slope.

Table 1

Plant species collected in four habitats during 1974 and 1975 at Gorrasis $\left(25^{\circ} 18^{\prime} \mathrm{S}, 15^{\circ} 55^{\prime} \mathrm{E}\right.$, South West Africa/Namibia).

\begin{tabular}{|c|c|c|c|c|c|}
\hline Family & Species & Dunes & $\begin{array}{c}\text { Gravel } \\
\text { Plain }\end{array}$ & $\begin{array}{l}\text { Rock } \\
\text { Plain }\end{array}$ & $\begin{array}{l}\text { Bush } \\
\text { Plain }\end{array}$ \\
\hline ACANTHACEAE & $\begin{array}{l}\text { Petalidium serosum } \\
\text { Monechme desertorum }\end{array}$ & & & $x$ & $x$ \\
\hline AMARANTHACEAE & Amaranthus schinzianus & & & $x$ & \\
\hline & Caloricorema capitata & & & $x$ & \\
\hline $\begin{array}{l}\text { BIGNONIACEAE } \\
\text { CHENOPODIACEAE }\end{array}$ & Rhigozum trichotomum & & & & $\begin{array}{l}x \\
x\end{array}$ \\
\hline COMPOSITAE & Hirpicum gazanoides & & & $x$ & $\hat{x}$ \\
\hline CURCUBIT ACEAE & Cucumis meeusei & $x$ & & & \\
\hline GRAMINEAE & $\begin{array}{l}\text { Aristida adscensionis } \\
\text { Enneapogon scaber }\end{array}$ & & $x$ & $\dot{x}$ & $\stackrel{x}{x}$ \\
\hline & $\begin{array}{l}\text { Schmidtia kalahariensis } \\
\text { Stipagrostis ciliata } \\
\text { S. hirtugluma }\end{array}$ & $\begin{array}{l}x \\
x\end{array}$ & $\hat{\imath}$ & $\begin{array}{l}x \\
x\end{array}$ & $\begin{array}{l}x \\
x .\end{array}$ \\
\hline & & & $x$ & $\begin{array}{l}x \\
x\end{array}$ & $\begin{array}{l}x \\
x\end{array}$ \\
\hline LEGUMINOSEAE & $\begin{array}{l}\text { Crotalaria damarensis } \\
\text { C. agyraea } \\
\text { C. virgultalis } \\
\text { Indigofera auricoma }\end{array}$ & $x$ & & $x$ & $\begin{array}{l}x \\
x\end{array}$ \\
\hline \multirow{5}{*}{$\begin{array}{l}\text { MARTYNIACEAE } \\
\text { RUBIACEAE } \\
\text { SCROPHULARIACEAE } \\
\text { STERCULACEAE } \\
\text { ZYGOPHYLLACEAE }\end{array}$} & $\begin{array}{l}\text { 1ndigofera auricoma } \\
\text { Sesamum capense }\end{array}$ & & & & $x$ \\
\hline & Kohautia caespitosa & $x$ & $x$ & & $x$ \\
\hline & $\begin{array}{l}\text { Aptosimum spinescens } \\
\text { Hermannia modesta }\end{array}$ & & & $x$ & $x$ \\
\hline & Tribulus sp. & & & & $x$ \\
\hline & Total number of species & 5 & 4 & 13 & 16 \\
\hline
\end{tabular}

The rock plain grid was located on a northeast-facing approximately $5^{\circ}$ slope. Soil at this site was sandy and was overlaid by igneous rock rubble (mostly $2-4 \mathrm{~cm}$ in diameter but some up to about $30 \mathrm{~cm}$ ). The bush plain grid was located on the level floor of a broad intermontane valley. Soil was loose $\operatorname{san} 1$ and gravel and overlaid a layer of partially exposed calcrete.

Plant species collected in each of these habitats are shown in Table 1. Grasses. were the dominant plants in each habitat, reaching heights of about $1 \mathrm{~m}$ on the dune area and 15-50 $\mathrm{cm}$ on the other three areas. Sparse bushes (Rhigozur/ trichotomum Burch., up to about $70 \mathrm{~cm}$ height) were found on the bush plain 
area. Graises were distributed uniformly over the dune grid, whereas vegetation was spatally more heterogeneous on the other areas. Vegetative growth had begun at the start of the study in early February 1974, and seed production occurred before April of that year. From May 1974 until after the 1975 rains, grasses were dry and seeds abundant on the ground surface. Seed production in 1975 was completed by the termination of the study in early May 1975.

\section{METHODS}

Demognphic data were obtained by mark-and-recapture live-trapping on one grid in e:ch of the areas described above. In the bush plain habitat, 144 trap stations vere arranged in a 12 by 12 pattern at $15 \mathrm{~m}$ spacing; this area was trapped every two weeks. In each of the other three habitats, 100 trap stations were placed in a 10 by 10 pattern at the same interval. These areas were trapped monthly. Che grid in the bush plain habitat and those in the other three habitats were probably sufficiently large that the effects of size differences between them on measued parameters were minor. One folding Sherman live-trap ( 23 by 9 by $7.5 \mathrm{~cm}$ ) was placed at each trap station and baited with a mixture of rolled oats and peanit butter. Each trap period consisted of three consecutive nights. Traps were set and baited within 2 hours before dark, checked and closed early the next day, and baited and re-set the following evening. Each trap period ended when trais were closed on the third morning. Trapping began in mid-February on the dune grid, early March in the bush plain habitat, mid-April in the rock plain habtat, and early May in the gravel plain.

Upon frst capture, each animal was toe-clipped for individual identification. At first cupture in each trap period, the data recorded for each animal included its identification number, species, sex, reproductive status, location on the grid, and body mass to the nearest $\mathrm{g}$ (measured with a $100 \mathrm{~g}$ capacity Pesola scale). At subsecuent captures within each trap period, only the animal's identification number and its location on the grid were noted. Reproductive activity was assessed y the position of the testes (scrotal or abdominal) in males and the condition of the vaginal opening (perforate or nonperforate) and the size of the nipples (snall, medium, or large) in females.

Demogriphic data were analyzed on the Michigan State University Computer Laborator CDC-6500, using a computer package written by Walt Conley, New Mexico Sate University. Population sizes were estimated as the minimum number alive usin; direct enumeration ( $\mathrm{Kre} \mathrm{b} \mathrm{s}, 1966$ ).

\section{RESULTS}

\subsection{Population Growth and Recruitment}

Demographic data described below are based on 6,205 captures on 1,243 incividuals. Only the most common rodent species on each area are consdered. These were, in the dunes, gravel plain, and bush plain habitats, two gerbilline rodents, Gerbillurus paeba A. S mith, 1836 (adult bidy weights $20-30 \mathrm{~g}$ ) and Desmodillus auricularis (A. S m it h, 1834) (acult weights up to about $75 \mathrm{~g}$ ), and in the rock plain habitat, 
D. auricularis and a murine rodent, Aethomys namaquensis (A. S m it h, 1834) (adult weights $40-50 \mathrm{~g}$ ).

As described earlier, rainfall in the eastern Namib Desert in 1973, a year prior to the start of this study, was poor. Rodent densities declined markedly between 1973 and 1974, presumably as a result of that failure of rains. Rodents had been abundant on the study areas in February, 1973 (R. H. Baker, unpublished data). At the beginning of the present

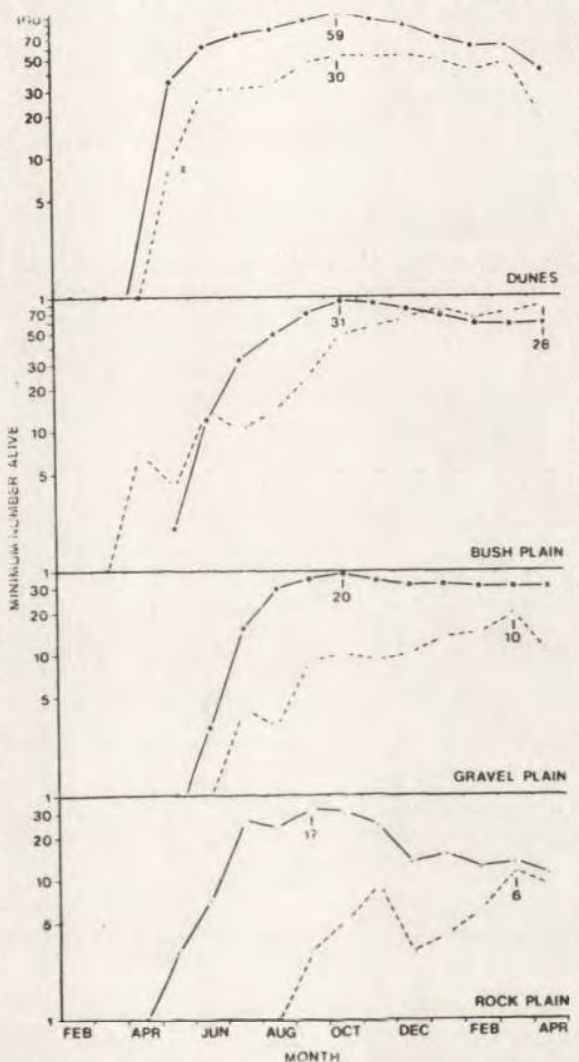

Fig. 1. Population sizes of Gerbillurus paeba (closed circles, solid lines), Desmodillus auricularis (open circles, dashed lines), and Aethomys namaguensis (open triangles, solid lines) in four habitats during 1974 and 1975. Population size estimated as minimum number alive by direct enumeration ( $\mathrm{Krebs}, 1966$ ). Number below each population curve is peak density (number of animals per ha of live-trap grid).

study in early 1974, rodent populations consisted of only widely-scattered individuals. In 2,928 trap-nights through April, 1974 on the bush plain, dunes, and rock plain grids, only 19 individuals were captured ( 0.65 animals per 100 trap-nights), and extensive surveys revealed only a very few active rodent burrows in the four major habitats. 
Density began to increase following the rains at the start of this study, and substantial numbers of rodents began to appear in May on the dune and bush plain grids and in July on the other two areas (Fig. 1). Populations of both gerbil species reached peak numbers in late October on the dune grid. In the other two habitats where they occurred together, G. paeba numbers peaked in September or October and D. auricularis in March or April. On the rock plain area, the pattern of population growth for $A$. namaquensis was comparable to that of the G. paeba populations. Desmodillus auricularis did not appear in that habitat until August and did not reach peak numbers until the following March. Peak density, computed as minimum number of animals per ha of live-trap

Table 2

Instantaneous rates of increase in population size $(r)$ per month in Gerbillurus paeba (=G.p.),Desmodillus auricularis $(=D . a$.$) and Aethomys namaquensis (=A, n$. during 1974 and 1975. Horizontal line in column of $r$ 's separates increase phase from decline phase. Values of $r=0$ have been entered for mean rate of decline in $D$. auricularis populations which showed no decline.

\begin{tabular}{|c|c|c|c|c|c|c|c|c|}
\hline & G. $\begin{array}{l}\text { Dur } \\
\text {. }\end{array}$ & $\begin{array}{l}\text { mes } \\
\text { D. } a .\end{array}$ & $\begin{array}{c}\text { Gravel } \\
\text { G. } p .\end{array}$ & $\begin{array}{l}\text { Plain } \\
D, a .\end{array}$ & $\begin{array}{l}\text { Bush } \\
\text { G. p. }\end{array}$ & $\begin{array}{l}\text { Plain } \\
\text { D. a. }\end{array}$ & $\begin{array}{l}\text { Rock } \\
\text { A. } n \text {. }\end{array}$ & $\begin{array}{l}\text { Plain } \\
\text { D. } a .\end{array}$ \\
\hline March 1974 & - & - & - & - & - & 1.946 & - & - \\
\hline April & $3.555^{1}$ & 2.197 & - & - & - & -.562 & 1.099 & - \\
\hline May & .554 & 1.203 & - & - & 1.792 & 1.253 & .846 & - \\
\hline June & .166 & .000 & 1.609 & 1.386 & .982 & -.342 & 1.272 & - \\
\hline July & .166 & .05 & .658 & -.288 & .425 & .336 & -.083 & - \\
\hline Aug. & .157 & .35 & .131 & 1.099 & .329 & .536 & .300 & 1.099 \\
\hline Sept. & .131 & .122 & .086 & .104 & .215 & .713 & -.030 & .513 \\
\hline Oct. & -.117 & -.020 & -.083 & -.105 & -.041 & .131 & -.223 & .588 \\
\hline Nov. & -.083 & .000 & -.062 & .1 & -.0 & .1 & -.616 & -1.109 \\
\hline Dec. & -.223 & -.062 & .030 & .262 & -.128 & .157 & .140 & .285 \\
\hline Jan. 1975 & -.139 & -.17 & -.030 & -.077 & -.128 & -.139 & -.223 & .405 \\
\hline Feb. & .020 & .140 & -.030 & .307 & -.030 & .077 & .077 & .604 \\
\hline Mean $r$ & .381 & .350 & .257 & .327 & .334 & .353 & .233 & .341 \\
\hline increase & .788 & .661 & .621 & .327 & .749 & .353 & .687 & .341 \\
\hline decline & -.108 & -.023 & -.035 & .000 & -.080 & .000 & -.146 & .000 \\
\hline
\end{tabular}

${ }^{1}$ Computed with a population size of 1 in April, even though no animals were captured.

grid area, varied considerably among species and habitats (Fig. 1). The dunes habitat supported the highest densities of both of the gerbils, although peak densities of $D$. auricularis differed only slightly between that habitat and the bush plain area. Of those habitats where they coexisted, the gravel plain was the least productive for these two species. Aethomys namaquensis, $D$. auricularis in the dune habitat, and all three G. paeba populations declined subsequent to reaching peak population size, although, as discussed in more detail below, the rate of decline 
varied considerably among populations. These decreases in population size were not apparent in the other three D. auricularis populations. Any marked declines during the final $1-2$ trap periods are probably an artifact of capturing less than 100 per cent of the minimum number alive in each of those periods.

Instantaneous rates of increase in population size $(r)$ per month are shown in Table 2. Data for the last several trap periods have been excluded from this analysis to avoid bias due to the problem mentioned in the preceeding paragraph. Overall mean rates of increase from the time of initial population growth through February 1975 varied little among species and areas, except for the relatively low overall rates of growth for $G$. paeba in the gravel plain habitat (mean $r=.257$ ) and for $A$. namaquensis (mean $r=.233$ ). In all habitats except the dunes, D. auricularis exhibited rates of increase greater than zero ('ndicating an increase in population size) in a higher proportion of the trap periods than did the other species occupying that habitat.

Patterns of ipcrease were examined in further detail by computing separate mean instantaneous rates of increase for the period preceeding attainment of peak population size and for the period of decline after peak numbers were reached (Table 2). In all habitats, $D$. auricularis grew to peak size more slowly than the other species found in that habitat. As described earlier, only in the dunes habitat did this species reach peak numbers before March 1975, and the rate of increase during the period before maximum size was reached was considerably higher in that habitat than for populations of this species on the other three areas. Aethomys namaquensis and all three populations of G. paeba increased rapidly during the increase phase, with mean instantaneous rates of increase that approximate a doubling in population size each month. There is a striking relationship between the mean rate of growth during the period of increasing population size and the mean rate of decline subsequent to that time. For example, in the three populations of G. paeba these rates are highly inversely correlated $(r=-.986)$. Among all eight populations the mean rate of increase and the mean rate of decline are significantly inversely correlated $(r=-.797, P<.05 ;$ computations made using mean values shown in Table 2). Thus, those populations which grew most rapidly to peak numbers also exhibited the highest rates of decline after maximum population size was reached.

Recruitment was measured as the appearance on an area of previously unmarked animals. Tallies of newly-captured animals in a trap period were made without regard to age, and include immigrants as well as animals born on the area. The mean date of recruitment (computed using a formula by Ca ughley, 1977 for mean date of births) was used as 
a basis for comparing populations. Differences in this parameter generally paralleled those in population growth, with the mean date for $D$. auricularis recruitment being at least one month later than for G. paeba in bush plain (mid-October versus mid-September) and gravel plain habitats (mid-December versus mid-October) and slightly less than one month in the dunes habitat (mid-October versus late September). Mean date of recruitment for $A$. namaquensis (early September) was several weeks earlier than that of the three G. paeba populations and preceeded by about four months that of $D$. auricularis in the same habitat. Recruitment rate and instantaneous rate of increase at each trap period were highly correlated with each other for most populations. The only clearly nonsignificant correlation was for $D$. auricularis in the gravel plain habitat $(r=.335)$; the correlation for this species on the rock plain grid was marginally non-significant $(r=.714, \mathrm{n}=7, .05<P<.10)$. In the other populations these correlations were significant (highest $P<.05$ ) with values of $r=.532(\mathrm{n}=25)$ and $r=.654(\mathrm{n}=22)$ in, respectively, bush plain D. auricularis and G. paeba and values greater than $r=.780$ for the other population. Thus, varying rates of appearance of new animals were reflested in changing rates of population growth for most populations.

\subsection{Reproduction}

Available litter size data are not sufficient to evaluate age-specific, seasonal, or habitat differences. Mean litter size for snap-trapped specimens from all habitats throughout the study was 4.2 in G. paeba, 3.5 in A. namaquensis, and 2.5 in D. auricularis.

Breeding intensities, expressed as proportions of the total number of each sex captured in each trap period without regard to age, are shown in Tables 3 and 4 . Breeding measures for animals in the bush plain habitat are means of the breeding proportions observed in the trap periods in each month. Sample sizes of $D$. auricularis on the rock plain grid were too small to allow reliable estimation of breeding activity, although it appeared that reproductive success was low in that population. Similarly, the low numbers on all grids in the early months of the study precluded examination of breeding intensity during that period. Reproductive activity was high in most populations throughout at least a portion of the winter months (June through early September). Breeding intensity subsequently declined during parts of the hot, dry months of September through February, with different populations varying in the degree and timing of reduced reproductive activity.

Aethomys namaquensis showed some breeding activity throughout most of the year, as did most of the other populations. However, pro- 
portions of animals in breeding condition declined in July 1974, were low until December and then increased, remaining relatively high for the duration of the study. No lactating females were observed between December 1974 and March 1975.

Table 3

Proportions of Gerbillurus paeba and Desmodillus auricularis in breeding condition in three habitats during 1974 and 1975. Values for bush plain habitat are means of values observed in biweekly trap periods in each month. (scr. $=$ scrotal testes; perf.=perforate vaginal opening; lac.=lactating).

\begin{tabular}{|c|c|c|c|c|c|c|}
\hline \multirow{3}{*}{ Month } & \multicolumn{2}{|r|}{ Dunes } & \multicolumn{2}{|c|}{ Gravel Plain } & \multicolumn{2}{|c|}{ Bush Plain } \\
\hline & Male & Female & Male & Female & Male & Female \\
\hline & & perf. lac. & scr. & perf. lac. & scr. & perf. lac. \\
\hline
\end{tabular}
G. paeba

$\begin{array}{lrrr}\text { May } 1974 & .93 & .81 & .52 \\ \text { June } & .57 & .26 & .58 \\ \text { July } & .06 & .00 & .09 \\ \text { Aug. } & .14 & .00 & .06 \\ \text { Sept. } & .00 & .00 & .04 \\ \text { Oct. } & .08 & .00 & .00 \\ \text { Nov. } & .16 & .09 & .00 \\ \text { Dec. } & .61 & .21 & .10 \\ \text { Jan. } 1975 & .73 & .30 & .00 \\ \text { Feb. } & .77 & .20 & .00 \\ \text { Mar. } & 1.00 & .62 & .10 \\ \text { Apr. } & .94 & 1.00 & .84\end{array}$

$\begin{array}{rrrrrr}\overline{1.00} & - & - & 1.00 & .50 & 1.00 \\ 1.00 & .78 & \overline{.44} & .94 & .42 & .42 \\ .77 & .33 & .33 & .78 & .59 & .51 \\ .80 & .27 & .27 & .52 & .36 & .27 \\ .53 & .14 & .14 & .50 & .25 & .14 \\ .30 & .18 & .09 & .59 & .24 & .20 \\ .80 & .30 & .10 & .82 & .11 & .09 \\ .83 & .08 & .00 & .96 & .30 & .10 \\ 1.00 & .18 & .00 & .98 & .36 & .14 \\ .87 & .37 & .00 & .92 & .54 & .24 \\ 1.00 & 1.00 & .08 & .94 & .59 & .29\end{array}$

D. auricularis

\begin{tabular}{lrrrrrrrrr} 
May 1974 & 1.00 & 1.00 & .00 & - & - & - & .75 & .75 & .50 \\
June & .81 & 1.00 & .25 & - & - & - & .90 & .50 & .50 \\
July & .65 & .60 & .50 & .50 & .50 & .00 & 1.00 & .30 & .20 \\
Aug. & .77 & .70 & .50 & 1.00 & 1.00 & 1.00 & .83 & .59 & .30 \\
Sept. & .41 & .32 & .16 & .67 & .83 & .17 & .54 & .69 & .22 \\
Oct. & .37 & .25 & .05 & .00 & .50 & .00 & .43 & .68 & .30 \\
Nov. & .08 & .50 & .19 & .00 & .33 & .00 & .38 & .44 & .20 \\
Dec. & .24 & .54 & .23 & .67 & .40 & .00 & .30 & .60 & .20 \\
Jan. 1975 & .56 & .82 & .06 & .40 & .33 & .00 & .48 & .47 & .22 \\
Feb. & .50 & .40 & .10 & .62 & .40 & .00 & .37 & .55 & .12 \\
Mar. & .70 & .74 & .26 & .67 & .71 & .14 & .32 & .65 & .17 \\
Apr. & .43 & .67 & .25 & .50 & .50 & .33 & .34 & .56 & .09 \\
\hline
\end{tabular}

Reproductive seasonality was more pronounced in G. paeba than in $D$. auricularis, and in $G$. paeba was particularly marked in the dunes habitat. On that area, no female G. paeba were observed in breeding condition between July and October 1974, and relatively low breeding intensities occurred in June and from November through February. Reproductive activity in both sexes of that population increased sharply after the period of reduced breeding, although proportions of males with 
scrotal testes began to increase in December, several months before high proportions of females were observed in breeding condition.

Similar trends were observed in G. paeba in the other two habitats, but declines in reproductive activity were slight compared to those on the dune grid. Differences in breeding intensity between areas in each month were examined by comparing numbers of breeding and nonbreeding animals in $2 \times 2 \chi^{2}$ contingency tables. These tests indicated few consistent differences in either male or female G. paeba breeding intensities between gravel plain and bush plain habitats. Significantly greater numbers of this species (both males and females) were in breeding condition on each of these two areas than on the dune grid in at least four months between July 1974 and January 1975 (highest $P<.05$ ).

Table 4

Proportions of Aethomys namaquensis in breeding condition in rock plain habitat during 1974 and 1975. Abbreviations follow Table 3 .

\begin{tabular}{|c|c|c|c|}
\hline Month & $\begin{array}{l}\text { Male } \\
\text { scr. }\end{array}$ & \multicolumn{2}{|c|}{ Female } \\
\hline May 1974 & .50 & 1.00 & 1.00 \\
\hline June & 1.00 & 1.00 & .33 \\
\hline July & .64 & .70 & .20 \\
\hline Aug. & .62 & .33 & .11 \\
\hline Sept. & .36 & .20 & .27 \\
\hline Oct. & .36 & .40 & .20 \\
\hline Nov. & .55 & .60 & .20 \\
\hline Dec. & .17 & .25 & .00 \\
\hline Jan. 1975 & .87 & .50 & .00 \\
\hline Feb. & .83 & 1.00 & .00 \\
\hline Mar. & .83 & .50 & .00 \\
\hline Apr. & .80 & 1.00 & .75 \\
\hline
\end{tabular}

In addition to these differences in breeding proportions during the dry season, reproductive events in G. paeba appeared to occur earlier in the dune habitat than in gravel plain, suggesting that the former may be a more strongly seasonal habitat. In both male and female G. paeba, breeding proportions on the dune grid and those in coeval periods in gravel plain were not significantly correlated $(r=.488$ for males and $r=.553 \mathrm{for}$ females). However, these correlations are significant if, rather than using coeval data, breeding proportions on the dune grid are compared with those on the gravel plain area one month later (for males, $r=.756, P<.01$; for females, $r=.607, P<.05$ ). Breeding proportions in $G$. paebo in the bush plain habitat were significantly correlated with those in both dune and gravel plain habitats (with dunes, $r=.800$, $P<.01$ for males and $r=.579, P<.05$ for females; both $\mathrm{n}=12$; with 
gravel plain, $r=.761, P<.05$ for males and $r=.747, P<.01$ for females: both $\mathrm{n}=11$ ). Thus, seasonal breeding patterns in this species appear qualitatively similar on all three areas, although the magnitude of breeding proportions and the timing of reproductive changes may vary among habitats.

Reproduction in D. auricularis was more aseasonal than in G. paeba, as was stated above and as would be predicted from the relatively aseasonal pattern of recruitment and population growth in most populations of this species. While breeding activity in D. auricularis (particularly in males) declined somewhat during the dry season, declines were considerably less marked than in G. paeba. Similarly, this species did not exhibit the sharp increases in breeding proportions seen in $G$. paeba at or near the end of the dry season. In several months during the period of June through October 1974, numbers of breeding D. auricularis males and females were significantly higher than those of G. paeba on all three areas where the two species coexisted (tested by $\chi^{2}$, highest $P<.05$, 5 differences in males and 9 in females on all three areas). These differences occurred during the portion of the year when marked declines in G. paeba reproduction were observed. Conversely, in several months following December 1974, when G. paeba breeding intensities were increasing, numbers of breeding animals of this species were significantly higher than in $D$. auricularis, particularly in males (highest $P<.05,11$ differences in males, 3 in females on all three areas). Thus, breeding activity was more evenly distributed throughout the year in $D$. auricularis than in G. paeba.

\subsection{Survivorship}

Survival rates were computed from data obtained by direct enumeration of marked animals ( $\mathrm{K} \mathrm{rebs}, 1966)$. For animals on the dunes, gravel plain, and rock plain areas these were expressed directly as survival rates per month. For animals in the bush plain habitat, these rates were computed as probabilities of surviving through two 2-week trap periods (i.e., survival rates per four weeks), and a mean value was computed for each month to use in comparisons with other areas (Table 5). Mean survival rates of most populations were relatively high, the major exceptions being in $D$. auricularis in the gravel plain and rock plain habitats. In general, survivorship was lowest during the early months of the study.

In each of the two gerbils, differences in survival rates between sexes and among areas and months were tested using a three-way analysis of variance and data from the dunes, gravel plain, and bush plain habitats. In G. paeba, results of this analysis indicated: (1) a significant 


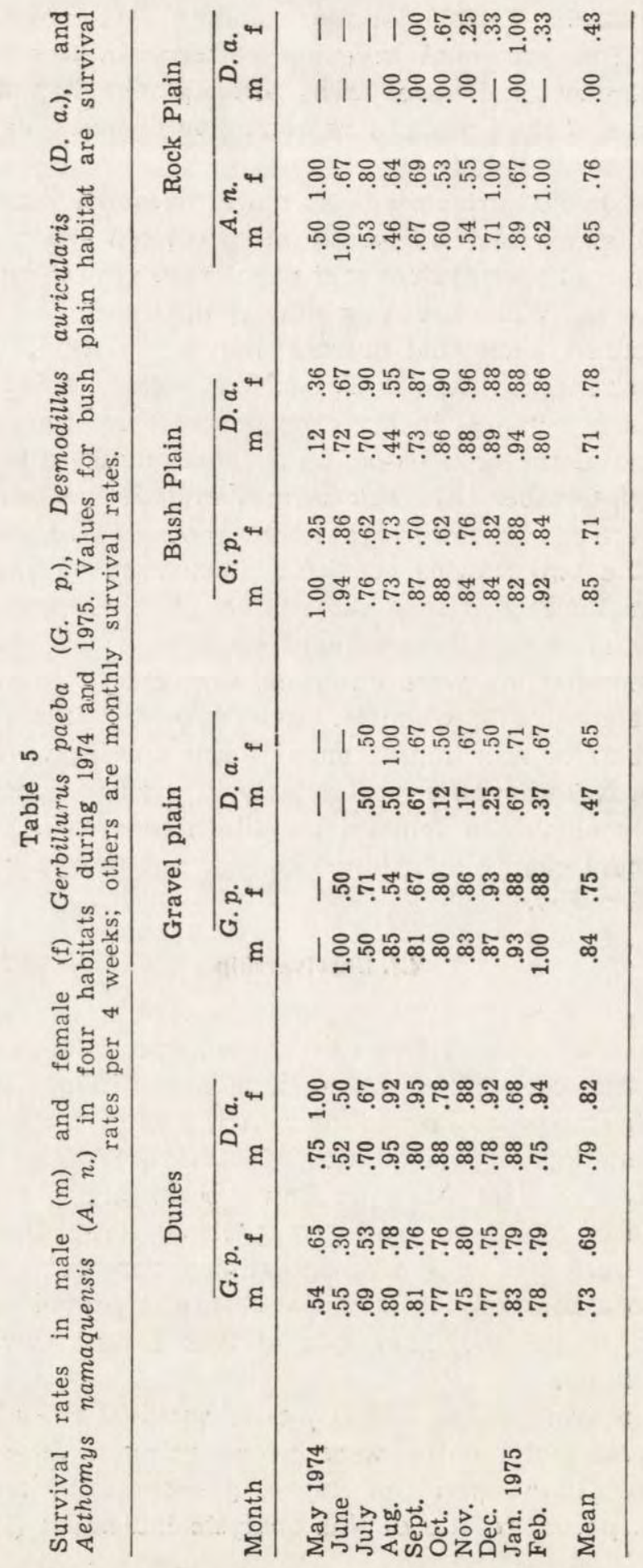


effect of sex on survival rates $(P<.025)$, with males having higher survival rates than females in all three habitats; (2) significant variation in survival rates among months $(P<.025)$; and (3) marginally nonsignificant habitat effects $(.05<P<.10)$, with survival rates on the dunes being somewhat lower than those on the other two areas. None of the interaction effects was significant. In D. auricularis, survival rates did not differ significantly among months $(P>.25)$. There was a significant effect of sex on survival rates, with females having higher survivorship than males $(P<.005)$, and a significant habitat effect $(P<.001)$, due primarily to the low survivorship in this species in the gravel plain habitat. However, interaction effects of habitat and time and of habitat and sex were significant $(P<.01$ and $P<.025$, respectively), indicating that sex differences in survival rates and temporal changes in survivorship were dependent on habitat.

The relationship between temporal variations in survival rates and those in instantaneous rates of increase in population size differed zonsiderably among populations. In all three G. paeba populations, pooled male and female survival rates were inversely correlated with rates of population growth, although significantly so only in the gravel plain habitat $(r=-.908, \mathrm{n}=9, P<.01)$. On the dune and bush plain areas, these correlations were, respectively, $r=-.498$ and $r=-.472$. A similar relationship was observed in bush plain $D$. auricularis $(r=-.666$, $\mathrm{n}=10, P<.05)$. Thus, in these populations survivorship was lowest during times of most rapid population growth. In $D$. auricularis on the dune area there was essentially no relationship between rate of growth and survivorship $(r=.071)$. In the remaining two $D$. auricularis populations and in $A$. namaquensis, survival rates were positively but not significantly related to population growth $(r=.384$ and $r=.649$ in rock plain and gravel plain $D$. auricularis, respectively, and $r=.414$ in $A$ : namaquensis).

Survival rates varied with breeding activity in several of the populations. The most striking relationship was observed in lactating G. paeba. In all three populations of this species, female survival rates in each month were significantly negatively correlated with the proportion of females that were lactating at that time (in dune, gravel plain, and bush plain habitats, respectively, $r=-.779, r=-.831$, and $r=-.838$; all $P<.01$ ). Similarly, in bush plain $D$. auricularis, survival rates of females were inversely correlated with the proportion lactating $(r=-.729, P<.05)$. Most of the other correlations between sex-specific survival rates and male and female breeding proportions were negative but not significant. The major exceptions were in $D$. auricularis on the gravel plain grid and in A. namaquensis, where all correlation coefficients between sur- 
vival rates and breeding measures were positive, although not significant $(r$ 's between +.220 and +.583$)$.

\section{DISCUSSION}

This study was initiated on several populations of desert rodents whose densities had been drastically reduced following an apparent reproductive failure the previous year. In spite of the notably high longevity of many small desert-dwelling rodents (F re $\mathrm{nch}$ et al., 1966, 1967, 1974; H a yden \& Lind berg, 1976), it would appear that probabilities of local extinction may be quite high in such low density populations. We unfortunately have little information on that problem. Conle y et al. (1977), using data from $\mathrm{Fr}$ e $\mathrm{ch}$ et al. (1974), found that most simulated populations of Perognathus formosus retained the ability to recover after up to three successive years of no reproduction, but several of the simulated populations went extinct following a three year breeding pause. All populations in the present study were able to respond reproductively to the onset of favorable conditions subsequent to a one year breeding pause, although success varied among species and habitats. Droughts of greater than one year duration are not uncommon in parts of the Namib Desert, and the effects on these particular species of several successive nonreproductive years are not known.

Most of the populations responded rapidly to the rainfall and plant growth at the start of the study, confirming the previously-mentioned relationship between rodent reproduction and primary production. The observed instantaneous rates of increase in population size are extremely high, exceeding those reported even for many rapidly-expanding microtine rodent populations ( $\mathrm{Krebs}, 1966 ; \mathrm{Krebs}$ et al., 1973), and warrant several comments. First, rainfall and primary production in the first year of the study were exceptionally good, and there was likely little or no resource limitation on population growth. Secondly, the extremely low initial densities provide a natural analogy to a population introduced into a previously unoccupied habitat and increasing with few density constraints. These two factors thus provided ideal circumstances for the attainment of high rates of population growth. It should be noted that estimated population sizes in the first few trapping periods were very low $(0,1$, or 2 animals known alive), and a slight absolute error in these estimates could alter the computed rates of population growth. If the initial values are underestimates of the actual numbers of animals known alive on the areas, the population growth rates shown in Table 2 would exaggerate the actual growth rates. I have no evidence suggesting that population sizes were grossly underestimated, and believe that rates of increase reported here are reasonably representative of the real rates. 
An important question concerns the relative contributions to high growth rates of immigration and of recruitment of animals born in situ. These alternative forms of recruitment could not be distinguished in the trapping results. Of the three species, only $A$. namaquensis appeared to occur in relatively high densities in a refugial habitat (rocky outcrops and low mountains) at the start of the study. However, the importance of that refugial population to population growth of this species in the rock plain habitat is unclear. Population growth in $A$. namaquensis did not begin earlier than in the other species nor were growth rates higher, suggesting that mass immigration from a localized region of high density played no greater role in producing rapid population growth in this species than in the two gerbils. In $D$. auricularis and $G$. paeba, no isolated pockets of high density remained from the previous year, and it appears that any "refugium" for these species during drought years exists simply in the form of low density populations. In one instance, however, large-scale immigration almost certainly made a major contribution to rapid population growth in G. paeba. The rate of increase for this species in the dune habitat between April and May, 1974 ( $r$ of at least 3.555 , equivalent to a 35 -fold increase in population size) can be explained only by a large movement of animals onto the trapping grid. Snap-trapping in other dunes habitats during April, 1974, prior to the large increase in population size on the dune grid, revealed loci of several $G$, paeba each, primarily around large hummocks of grass on the dune crests. In February, G. paeba had been no more abundant in those locations than elsewhere. Thus, it appears that reproduction may have begun earlier in those specific localities than on the grid itself, with subsequent movement of a large number of animals onto the grid. In $D$. auricularis and the other populations of $G$. paeba, such early breeding loci were not identified. Initial rates of growth in these populations were sufficiently low to be explicable in terms of the appearance of offspring of only a few breeding females, without mass movement onto the trapping areas. Of course, population growth in $D$. auricularis in the rock plain habitat appeared to be initiated by the movement of a small number of animals onto that area in August 1974.

Except for slightly lower overall mean instantaneous rates of population growth in gravel plain $G$. paeba and $A$. namaquensis, there was renarkably little variation among populations in this parameter. Despite the similarity of those mean values, however, there was a basic dichotomy in growth patterns in these populations. Aethomys namaquensis, all populations of $G$. paeba, and the dune grid population of D. auricularis increased at high rates over relatively short periods of time. There was general synchronization of attainment of peak numbers among these 
populations, and all declined to some extent after that time. Conversely, mean monthly growth rates of the other three $D$. auricularis populations were lower, but these populations grew over a longer portion of the year and exhibited little or no subsequent decline. Thus, there was a general inverse relationship between rate of growth and length of time during which growth occurs in these populations. The performance of D. auricularis in the dune habitat was somewhat atypical. Differences in breeding pattern between that population and others of this species were no greater than those between gravel plain and bush plain populations. However, growth in the dune population was more similar to that of the $G$. paeba population than to $D$. auricularis in other habitats. Whether or not this is a consequence of the apparent greater seasonality of that habitat is not known.

Differences in rates and duration of population growth were related to differences in breeding patterns. Reproductive activity in most populations diminished during at least part of the dry season. In general, reproduction in G. paeba and A. namaquensis was considerably more seasonal than that in $D$. auricularis, with more pronounced declines in breeding activity during the hot, dry portions of the year and more marked increases in breeding in the following months. Christian (1979a) found that, when provided with drinking water, G. paeba and another species, Rhabdomys pumilio (Sparrmann, 1784) (which has a demographic pattern comparable to that of $G$. paeba and A. namaquensis) maintained higher breeding proportions during potentially water-stressful periods than did control animals. Breeding season length in these species thus is controlled at least in part by seasonal changes in the availability of resources which are critical for successful reproduction (B r e e d, 1975; Soholt, 1978; Yahr \& Kessler, 1975). This seasonality imposes a temporal limitation on reproduction and population growth. Correspondingly, in these two species and presumably $A$. namaquensis as well, there is a high premium on responding rapidly to the onset of favorable conditions and on completing reproduction and population growth in a short time period. In contrast, breeding proportions in $D$. auricularis were not increased by the experimental provision of drinking water (Christian, 1979a). That result, and the relatively aseasonal breeding pattern shown by this species, suggest a less direct influence of varying resource availability on reproduction. Because $D$. auricularis appears sapable of reproducing over a wider range of environmental conditions, rapid completion of population growth may be less critical for this species. Thus, population growth may occur at lower rates but over longer periods of time. These results indicate two rather different strategies of population growth in these species, and two different means 
of dealing with the strong seasonality that is characteristic of many desert environments.

$\mathrm{C}$ hristian (1979b) reported that free water needs of $D$. auricularis are lower than those of $G$. paeba and $R$. pumilio, and suggested that the greater water-conserving ability of $D$. auricularis is a major factor in its aseasonal demographic pattern. While extensive data on water conservation in $A$. namaquensis are not available, this species also appears less efficient in this regard than $D$. auricularis (personal observation). In addition to these physiological differences, the more seasonal species are characterized by smaller body sizes and the production of larger litters.

Recruitment and survivorship had varying effects on rates of population growth. Those populations which reached highest peak densities were characterized by high recruitment rates, suggesting good reproductive success, and a close association between high rates of appearance of new animals and high population growth rates. In the two lowest density populations (D. auricularis in gravel plain and rock plain habitats), recruitment rates were less closely related to rates of population growth; recruitment rates in these two populations were relatively low, probably indicating low reproductive success and/or high juvenile mortality. In these two populations and in $A$. namaquensis, which also attained comparatively low peak densities, high rates of increase in population size were more closely synonymous with high survival rates than in other populations. In fact, in most of the other populations, survival rates were lowest during times of most rapid population growth. In those populations exhibiting a decline phase after reaching peak numbers, survival rates were generally higher during the decline than previously, indicating that the decreasing numbers were due not to higher mortality but rather to reduced recruitment rates.

Survivorship in some desert rodents has been shown to be inversely related to precipitation and plant growth and therefore inversely related to reproductive activity (Conley et al., 1977; French et al., 1966, 1967). That is, survival rates appear to be highest during adverse conditions, presumably because relatively less time is spent above-ground, gathering food, searching for mates, and so on, and thus exposed to mortality factors, and a greater proportion of time is spent inactive in relatively secure burrows (C onley et al., 1977; French et al., 1966, 1967). The same general pattern was observed in the present study, with survival rates in most populations being inversely related to breeding proportions. The strongest relationship between breeding activity and mortality was seen in lactating females in one population of $D$. auricul- 
aris and in all three $G$. paeba populations. Several studies have demonstrated that lactation in small rodents produces increased demands for energy (Milla r, 1975; 1978; R a ndol ph et al., 1977) and water (Baverstock \& Watts, 1975; Smith \& McManus, 1975; Soholt, 1978). Results of the present study suggest that obtaining these additional recources, or fulfilling other requirements during lactation. may translate into increased mortality. While these data do not provide a direct demonstration that lactating females had lower survival rates than non-lactating animals, they strongly suggest that a major cost of reproduction in these animals may be associated with lactation (see Conley et al., 1977; Rosenzweig, 1974).

Acknowledgements: This research was supported by a grant from the Jens Touborg Fund to The Museum, Michigan State University. The cooperation of the South West Africa/Namibia Department of Nature Conservation and Tourism and C. G. Coetzee and staff members at the State Museum, Windhoek is gratefully acknowledged. I thank R. H. Baker for his suggestions at various stages of the research. Computer time was provided through an NSF RANN Analysis of Ecosystems Grant, no. GI-20, and was made available through the courtesy of W. E. Cooper. Numerous calculations were made on the Wang 600-14 calculator at the Michigan State University Museum. Manuscript preparation was supported by a Summer Research Appointment from the Graduate School, University of Minnesota. I wish to thank my wife Sandy and Thys and Antoinette Louw for their assistance and support during the field work.

\section{REFERENCES}

1. Baverstock P. R. \& Watts C. H. S., 1975; Water balance of small lactating rodents. I. Ad libitum water intakes and effects of water restriction on growth of young. Comp. Biochem. Physiol., 50A: 819-825.

2. Beatley J. C., 1969: Dependence of desert rodents on winter annuals and precipitation. Ecology, 50: 721-724.

3. Beatley J. C., 1976: Rainfall and fluctuating plant populations in relation to distribution and numbers of desert rodents in southern Nevada. Oecologia, 24: $21-42$.

4. Breed W. G., 1975: Environmental factors and reproduction in the female hopping mouse, Notomys alexis. J. Repro. Fert., 45: 273-281.

5. Caughley G., 1977: Analysis of vertebrate populations. John Wiley and Sons: $1-234$. New York.

6. Christian D. P., 1977: Comparative demography and water metabolism in three Namib Desert rodents. Ph. D. dissertation, Michigan State Univ., East Lansing, $124 \mathrm{pp}$.

7. Christian D. P., 1979a: Comparative demography of three Namib Desert rodents: responses to the provision of supplementary water. J. Mammal., 60: 679-690.

8. Christian D. P., 1979b: Physiological correlates of demographic patterns in three sympatric Namib Desert rodents. Physiol. Zool. 52: 329-339.

9. Coetzee C. G., 1969: The distribution of mammals in the Namib Desert and adjoining inland escarpment. Scient. Pap. Namib Desert Res. Sta., 40: $23-36$. 
10. Conley W., Nichols J. D. \& Tipton A. R., 1977: Reproductive strategies. in desert rodents. [In: Transactions-symposium on the biological resources of the Chihuahuan Desert Region, United States and Mexico*, R. H. Wauer, D. H. Riskind, eds.]. U. S. National Parks Service No 3: 193-215. Washington, D. C.

11. French N. R., Maza B. G. \& A schwanden A. P., 1966: Periodicity of desert rodent activity. Science, 154: 1194-1195.

12. French N. R., Maza B. G. \& Aschwanden A. P., 1967: Life spans of Dipodomys and Perognathus in the desert. J. Mammal., 48: 537-548.

13. French N. R., Maza B. G., Hill H. O., Aschwanden A. P. \& Kaaz. H. W., 1974: A population study of irradiated desert rodents. Ecol. Monogr., 44: $45-72$.

14. H a y den P. \& Lind berg R. G., 1976: Survival of laboratory-reared pocket. mice, Perognathus longimembris. J. Mammal., 57: 266-272.

15. Krebs C. J., 1966: Demographic changes in fluctuating populations of Microtus californicus. Ecol. Monogr., 36: 239-273.

16. Krebs C. J., Gaines M. S., Keller B. L., Myers J. H. \& Tamarin. R. H., 1973: Population cycles in small rodents. Science, 179: 35-41.

17. McCulloch C. Y. \& Inglis J. M., 1961: Breeding periods of the Ord kangaroo rat. J. Mammal., 57: 337-344.

18. Millar J. S., 1975: Tactics of energy partitioning in breeding Peromyscus. Can. J. Zool., 53: 967-976.

19. Milla r J. S., 1978: Energetics of reproduction in Peromyscus leucopus: the cost of lactation. Ecology, 59: 1055-1061.

20. Nichols J. D., Conley W., Batt B. \& Tipton A. R., 1976: Temporally dynamic reproductive strategies and the concept of $r$ - and $K$-selection. Amer. Natur., 110: 995-1005.

21. Randolph P. A., Randolph J. C., Mattingly K. \& Foster M. M., 1977: Energy costs of reproduction in the cotton rat, Sigmodon hispidus. Ecology, 58: $31-45$.

22. Reynolds H. G., 1958: Ecology of the Merriam kangaroo rat on the grazing. lands of southern Arizona. Ecol. Monogr., 28: 111-127.

23. Rosenzweig M. L., 1974. On the optimal above ground activity of bannertail kangaroo rats. J. Mammal., 55: 193-199.

24. Smith B. W. \& McM anus J. J., 1975: The effects of litter size on the bioenergetics and water requirements of lactating Mus musculus. Comp. Biochem. Physiol., 51A: 111-115.

25. Soholt L. F., 1978: Consumption of herbaceous vegetation and water during: reproduction and development of Merriam's kangaroo rat, Dipodomys merria$m i$. Amer. Midland Natur., 98: 445-457.

26. Yahr P. \& Kessler S., 1975 Suppression of reproduction in waterdeprived Mongolian gerbils (Meriones unguiculatus). Biol. Reprod., 12: 249 -254 .

Accepted, May 30, 1980. 
Donald P. CHRISTIAN

\section{ODNAWIANIE SIE POPULACJI Z NISKICH LICZEBNOSCI \\ U GRYZONI Z PUSTYNI NAMIB}

\section{Streszczenie}

W latach 1974 i 1975 badano zwiększanie się liczebności w 8 populacjach należących do trzech gatunków gryzoni zamieszkujących pustynię Namib. Wyjściowe zagęszczenia wszystkich populacji były krańcowo niskie w wyniku, wyraźnie wywołanego przez suszę, krachu rozrodczego $w$ poprzednim roku (Ryc. 1). W następstwie intensywnych opadów i wysokiej produkcji roślinnej na początku 1974 roku wszystkie populacje zaczęly powiększać swą liczebność (Tabela 1). Gerbillulus paeba, Aethomys namaquensis i jedna populacja Desmodillus auricularis podwajały mniej więcej co miesiąc swą liczebność. Osiągnęły one szczyt we wrześniu i pażdzierniku 1974 roku a następnie liczebność ich zaczęła spadać. Pozostałe populacje $D$. auricularis wzrastały wolniej, ale przez dłuższą część roku, osiągając szczytowe ilości w marcu i kwietniu 1975 r. (Tabela 2). Aktywność rozrodeza większości populacji spadała w porze suchej. Na ogół wzrost populacji był dodatnio skorelowany $z$ poziomem rozrodu i odwrotnie skorelowany z przeżywalnością (Tabela 3,4). Populacje o najniższych zagęszczeniach charakteryzowały się niskim przyrostem sugerującym albo znikomą rozrodczość albo wysoką śmiertelność młodych i wykazywały też zależności między tempem wzrostu i przeżywalnością. Przeżywalność większości populacji była odwrotnie skorelowana $\mathrm{z}$ aktywnością rozrodczą. Ten związek był szczególnie wyraźny u karmiących samic we wszystkich populacjach G. paeba i jednej populacji $D$. auricularis (Tabela 5). 